\title{
FIRE SAFETY EVALUATION OF AN UNDERGROUND CAR PARK USING NUMERICAL SIMULATION
}

\author{
Dan BURLACU - Eng.Alexandru Ioan Cuza Police Academy, Fire Officers Faculty, $₫$ burlacudan92@gmail.com \\ Ion ANGHEL - Lecturer PhD Alexandru Ioan Cuza Police Academy, Fire Officers Faculty, \\ $\triangle$ ion_anghel2003@yahoo.com \\ Constantin POPA - Eng., PhD, Fire Safety Association, Fire Research Department, $\triangle$ costi_popa001@yahoo.com \\ Ionuț CĂȘARU - Eng. Neron Lupașcu Buzău County Inspectorate for Emergency Situations, \\ $\triangle$ casaruionut@yahoo.com
}

\begin{abstract}
This paper presents a global fire risk assessment by using fire simulation in an existing underground parking. The simulation is conducted with the Fire Dynamics Simulator, a Computational Fluid Dynamics (CFD) tool and the simulations are performed on a threedimensional model of the parking. Multiple parameters and factors are taken into account in this complex assessment, such as geometry data, ventilation openings (both mechanical and natural), fire detection and fire suppression details. The output of the case study is represented by a large array of data: the time for sprinkler activation, maximum temperatures, smoke flow and overall fire evolution. The intention of the authors is to provide a global fire risk assessment of the parking, based on the fire safety engineering principles.
\end{abstract}

Keywords: underground parking, fire safety engineering, fire modeling, computer simulation, Computational Fluid Dynamics (CFD)

\section{Introduction}

Urban development led to a lack of space in the crowded cities, leading, in the recent years, to the need for parking spaces and, as a result, to the construction of underground car parks. In many cases, the new underground car parks are located at the basement of commercial or residential buildings. When assessing fire safety, the main feature of an underground car park is its confined space condition. In the event of a fire, the confined space characteristics lead to a large amount of smoke accumulation thus making evacuation difficult. Fire causes can vary from electrical malfunctions, engine sparks or overheated mechanical hardware, to careless smokers.

All fire safety strategies related to buildings imply a main current practice, putting first the lives and safety of the building occupants and the safety of fire service crews. Any design or assessment, based on prescriptive codes or performance-based codes, base their judgement on life safety, [1].

In order to better understand and design underground car parks, numerous tests need to be carried out. Although full-scale experiments would give relevant information about such fires, these tests are very expensive to be carried out. Having said this, numerical simulations come in handy, offering a cheaper alternative to full-scale fire tests.

CFD modelling of fires is becoming an increasingly important analytical tool for the fire safety engineers. As the understanding of fire related physical phenomena - such as combustion processes, heat transfer and fluid flow - increases, so does the ability to accurately model fires using fields models, [2].

The use of CFD for calculations of smoke movement in case of fire in complex buildings is increasingly popular. This is not only reflected in a large number of journal publications, but it is also becoming more and more a common practice in design calculations. The results presented in this paper are obtained after performing computer simulations of four fire scenarios, using Fire Dynamics Simulation software. The goal of the above mentioned simulations was to asses if the current solution adopted for the existing parking space provides an adequate response in case of different fire situations (depicted in the scenarios presented in chapter five). 
The parameters that vary within these simulations are: 1 . the fire load density values and 2 . the activity of the fire suppression sprinkler system. The fire suppression system acts upon the fire in two of the scenarios, but it is considered as being inactive in the other two.

\section{Mathematical modeling and computer simulation of fire}

The idea that the dynamics of a fire might be studied numerically dates back to the beginning of the computer age. The fundamental conservation equations governing fluid dynamics, heat transfer and combustion were first written down over a century ago. Despite this, practical mathematical models of fire as an event (as distinct from controlled combustion) are relatively recent due to the inherent complexity of the problem, [3].

Since the CFD techniques are fast and the results can be obtained at almost no cost, they are often used for modelling of fire dynamics and radiation simulations. CFD techniques include Reynolds-averaged Navier-Stokes equation (RANS) method, Large Eddy Simulation (LES) and Direct Numerical Simulation (DNS). LES has been widely applied to simulate the fire-induced flow, because it is a CFD method capable of predicting unsteadiness in turbulent flows, [4]. The Fire Dynamics Simulator (FDS) is an open-source CFD software package, being widely used for fire related studies, because it is suitable for a wide range of thermally driven flow scenarios, both outdoors and in a building environment. It is relatively fast and robust, and is an easy tool to work with, when implementing a fire scenario. This means that the user only has to specify a small number of numerical parameters, focusing instead on the physical description of the problem, and the rest is default data of the software, [3].

The FDS models can predict evolution of smoke, temperature, carbon monoxide and other substances during fires. The results of these simulations have been used to ensure the safety of buildings before construction, evaluate safety options of existing buildings, reconstruct fires for post-accident investigation and assist in training of firefighters, [5].

FDS is based on low Mach, Large Eddy Simulation (LES), meaning that it simulates fluid flow and behavior at speeds lower than the speed of sound. Therefore, it cannot simulate detonations or explosions. The Large Eddy Simulation describes the turbulent flow of fluids, under the influence of its surroundings. The equations for Large Eddy Simulation (LES) are derived by applying a lowpass filter, parameterized by a width $\Delta$, to the transport equations for mass, momentum and energy. For our purposes, it is sufficient to think of the filtered fields in the LES equations as cell means. For example, in one dimension, the filtered density for a cell of width $\Delta$ is:

$$
\bar{\rho}(x, t)=\frac{1}{\Delta} \int_{x-\Delta / 2}^{x+\Delta / 2} \rho(r, t) d r
$$

In FDS, the filter width $\Delta$ is equivalent to the local cell size $\delta \mathrm{x}$ and is a key parameter in the submodels for the turbulent viscosity and the reaction time scale discussed later. The practice of taking $\Delta=\delta \mathrm{x}$ is called implicit filtering. It is important to appreciate, however, that implicit filtering does not imply dissipative numeric data. FDS employs kinetic-energy-conserving central difference schemes for momentum with physically-based closures for the turbulent stress, [3].

Regarding the fluid dynamic model, in Cartesian coordinates, with the box-filter applied to LES, the filtered governing equations have the following forms:

Continuity equation:

$$
\frac{\delta \bar{\rho}}{\delta t}+\frac{\delta \bar{\rho} \widetilde{u_{J}}}{\delta x_{j}}=0
$$

Momentum equation:

Energy equation:

$$
\frac{\delta \bar{\rho} \widetilde{u_{l}}}{\delta t}+\frac{\delta \bar{\rho} \widetilde{u_{u}} \widetilde{u_{l}}}{\delta x_{j}}=\frac{\delta\left(\bar{p}-\overline{p_{0}}\right)}{\delta x_{i}}+\frac{\delta}{\delta x_{j}}\left[\mu\left(\frac{\delta \widetilde{u_{l}}}{\delta x_{j}}-\frac{\delta \widetilde{u_{l}}}{\delta x_{i}}-\frac{2}{3} \frac{\delta \widetilde{u_{k}}}{\delta x_{k}} \delta_{i j}\right)\right]+\bar{\rho} g_{i} \delta_{i 3}+\frac{\delta \tau_{i j}}{\delta x_{j}}
$$

$$
\frac{\delta \bar{\rho} c_{p} \tilde{T}}{\delta t}+\frac{\delta \bar{\rho} c_{p} \widetilde{u_{j}} \tilde{T}}{\delta x_{j}}=\frac{\delta \overline{P_{0}}}{\delta t}+\frac{\delta}{\delta x_{j}}\left(K \frac{\delta \tilde{T}}{\delta x_{j}}\right)+\frac{\delta h_{j}}{\delta x_{j}}+\widetilde{q_{c}}+\widetilde{q_{r}}
$$


Equation of state:

$$
\bar{p}_{0}=\bar{\rho} R \tilde{T} \sum \frac{\tilde{Y}_{S}}{M_{S}}
$$

Where $\tau_{i j}=-\bar{\rho}\left(\overline{u_{\imath} u_{j}}-\tilde{u}_{i} \tilde{u}_{j}\right)$ and $h_{j}=-\bar{\rho}\left(\overline{u_{j} T}-\tilde{u}_{j} \tilde{T}\right)$ are the sub-grid Reynolds stresses and sub-grid turbulent heat fluxes respectively. The sign "_," denotes normal filtering and " $\sim$ " denotes Favre filtering, [6].

\section{The characteristics of the underground parking used as a simulation environment}

The building used as a case study is an underground parking situated in a shopping centre in Buzău County, Romania. It consists of three compartments with a combined total area of 14.363 square meters, having 431 parking spaces. The parking has one level and the cars (also presented throughout the article as automobiles or vehicles) can enter or exit the space by using two openings, each of these openings being 6 meters wide by 2.5 meters high. Pedestrian access is facilitated by closed staircases connecting the ground floor of the building with the parking.

The structure of the building is not combustible, its combustible characteristics being given by the vehicles and materials present therein. In the event of a fire, there should be a minimum number of casualties, because of two reasons: the low number of people that can be present at any given time in the parking area and also because of the slow evolution of a possible fire. The fire compartments of the parking are separated with three hours fire resistant A1 fire reaction class walls and floors. The compartmentation of the parking can be observed in figure 1 .

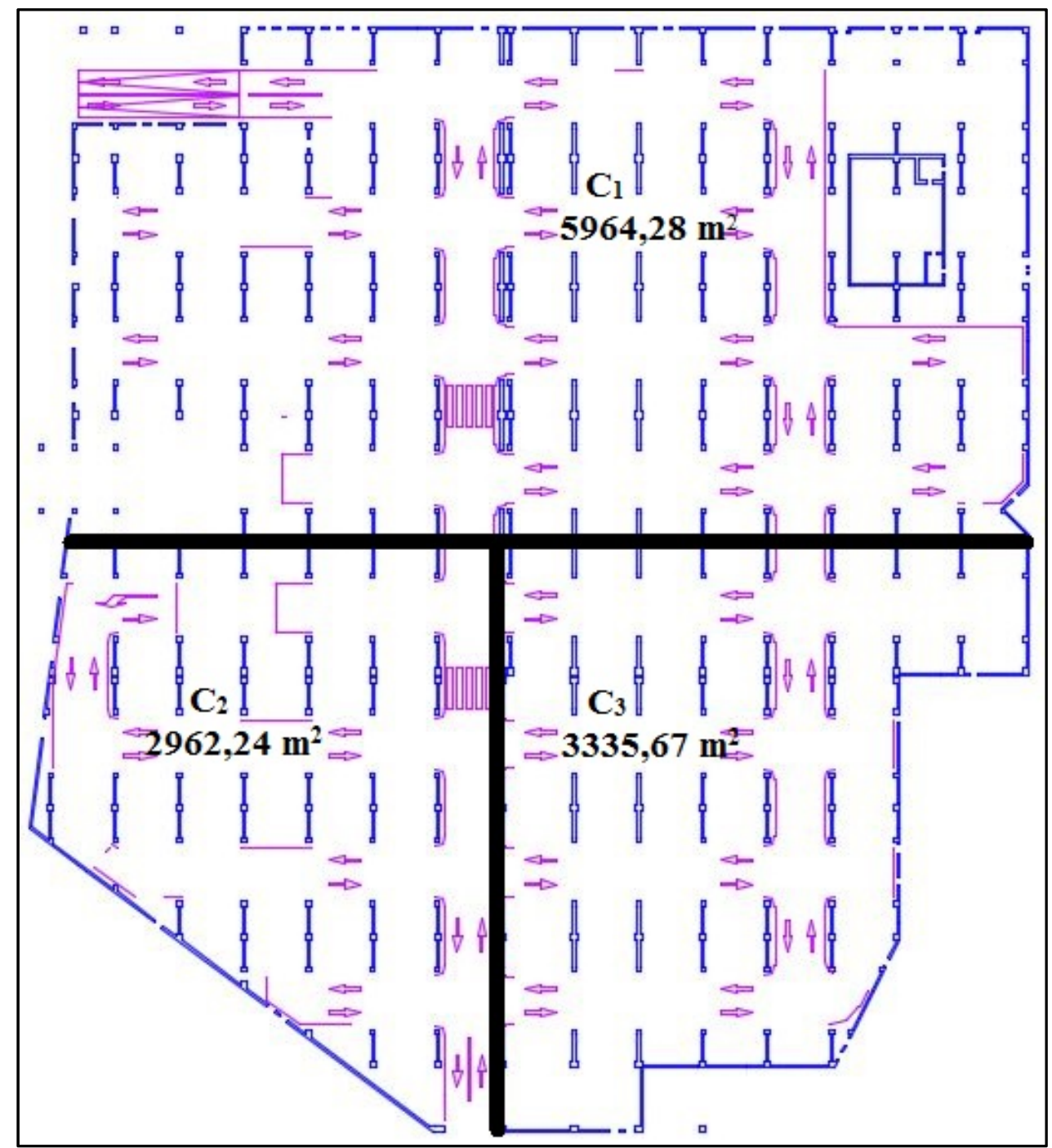

Fig. 1 - Underground parking slice view. One can observe the three fire compartments 
According to the documentation approved by the authorized fire brigade, the parking has been fitted with sprinklers, smoke detectors, extinguishers and interior fire hydrants. For the purpose of evaluating the impact that these security measures have on a possible fire, a dynamic simulation was needed. A dynamic simulation is based on parameters that change during the runtime of the simulation itself.

\section{Fire scenario choice procedure}

Compartment number three of the parking was chosen as a subject for the simulation. It has a surface of 3.335,67 square meters and hosts 134 parking spaces. The resistance structure of the compartment consists of concrete pillars, fire masonry walls and concrete floors, with supporting beams. The geometric configuration of the compartment is presented in figure 2 .

The parking is isolated with fire protected polystyrene, having a fire reaction class A2-s1, d0 on a fibreglass mesh support, in accord with the regulation in force, [7]. The virtual presentation of these elements can be viewed in figure 3. The ventilation openings that are used for HVAC and smoke evacuation are automatically activated after the detection of smoke, done by the use of smoke detectors.

In case of fire in underground facilities such as tunnels or car parks, while heat release rate (HRR) is crucial for the behaviour of the building and for the flow of fire effluents, impact on people is mainly governed by the smoke toxicity. Fire tests also show the importance of toxic gas emissions, [8].

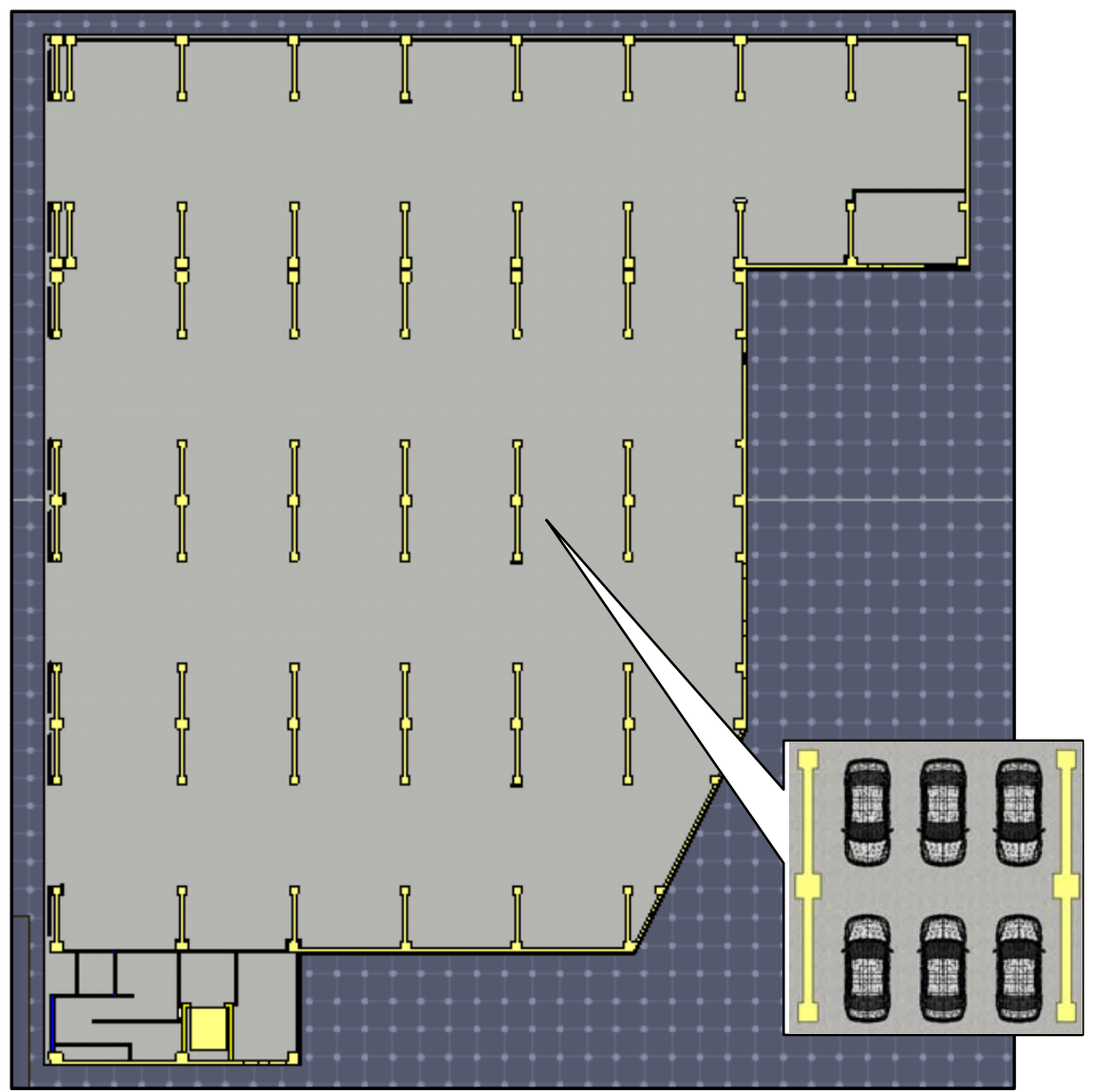

Fig. 2 - The geometry of fire compartment number three, as viewed in Fire Dynamics Simulator

Additional fire safety is ensured through the sprinkler system, interior hydrants and portable fire extinguishers, all in accordance with the Regulations for design, execution and service of fire extinguishing installations, [9] and the Regulations for the design of underground public buildings [10], that were in force when the building was designed and constructed. Fire hydrants 
and fire extinguishers are not used throughout the scenarios, but they are presented visually because they occupy the space and give a real view of the fire scene. Nevertheless, the smoke detectors and sprinkler systems trigger events and act on the fire.

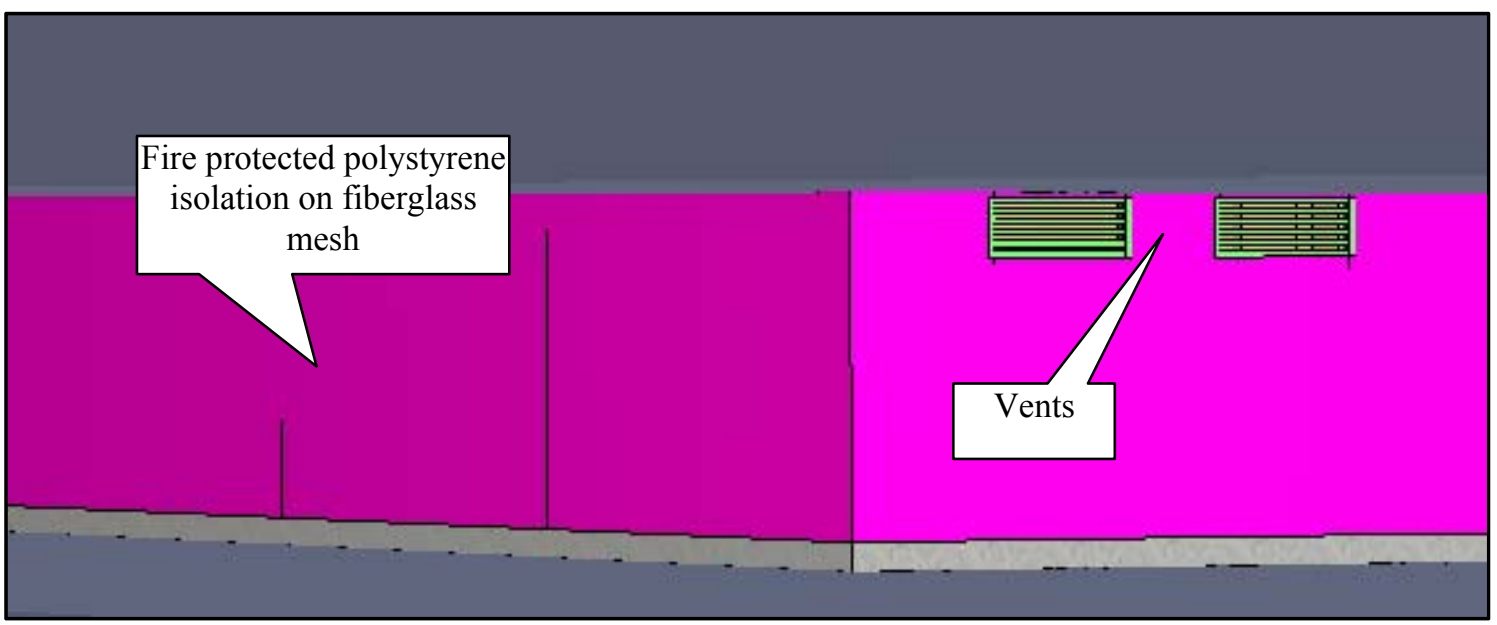

Fig. 3 - Presentation of vents and thermal isolation in Fire Dynamics Simulator

The 60 minutes EI fire resistance (E - integrity separation function, I - thermal insulating separation function) walls inside the fire compartment are made of fire protected drywall on a steel structure, in accordance with article 23 of the Regulation of fire security for underground car parks, [7]. Also the doors inside the fire compartment are either pivoting or sliding doors, have an EI 30-C (C - self closure) fire resistance and are fitted with evacuation openings/fittings, in accordance with article 74 of the same regulation. The virtual presentation of the above mentioned elements can be observed in figure 4 below.

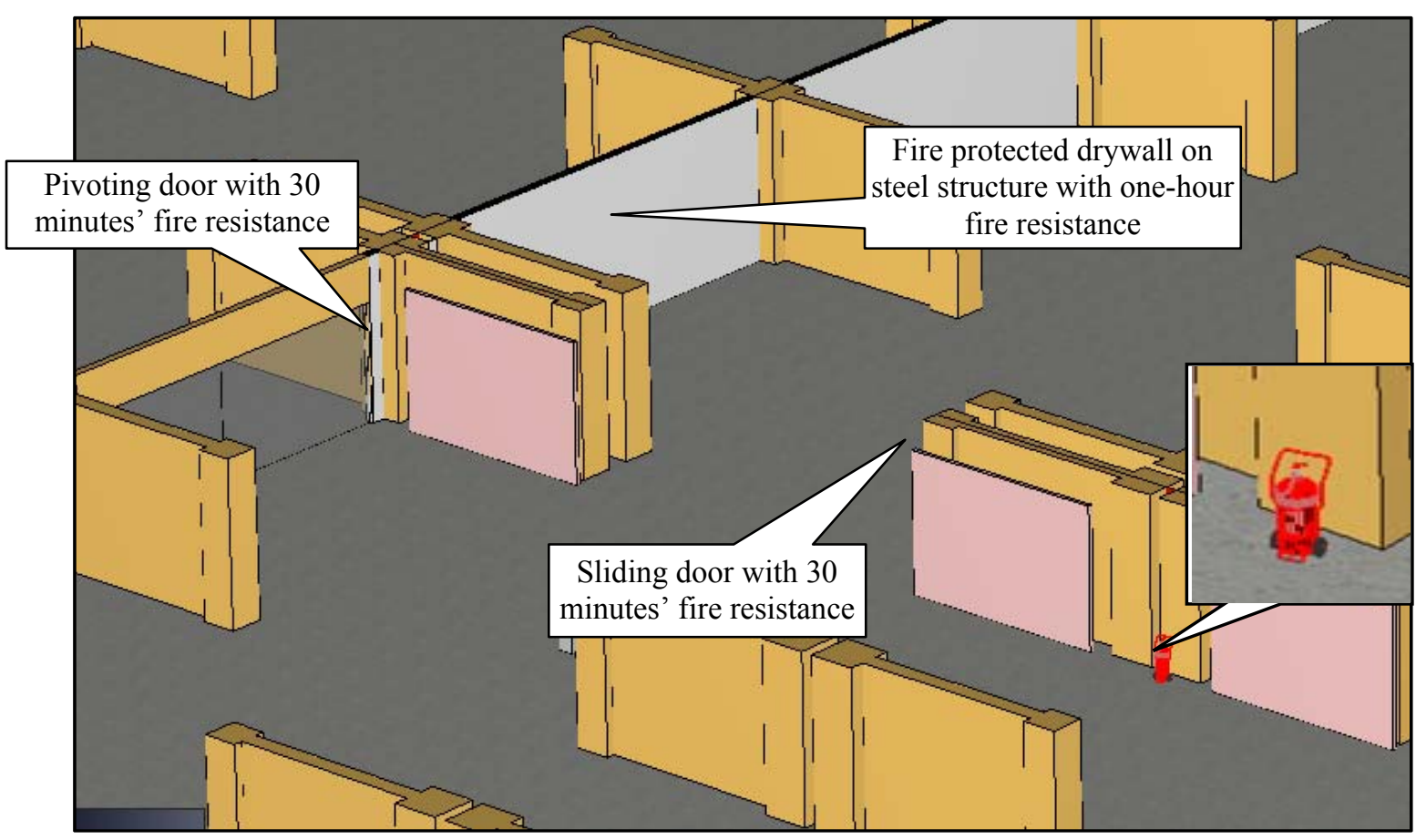

Fig. 4 - Compartmentation characteristics

\subsection{The implementation and running of the fire simulation}

The input information that constituted the basis for the simulation is presented in table 1 . The heat release rate for the car has been chosen to represent the ignition of a single old automobile, according to tested fire scenarios, [11]. 
Table 1

Input information

\begin{tabular}{|c|c|c|c|}
\hline Category & Parameters & \multicolumn{2}{|c|}{ Value } \\
\hline \multirow[b]{2}{*}{$\begin{array}{l}\text { Calculus } \\
\text { domain }\end{array}$} & Compartment 3 & \multicolumn{2}{|c|}{ Compartment 3 of an underground parking in a commercial center. } \\
\hline & $\begin{array}{l}\text { Size of compartment in } \\
\text { which the simulation is } \\
\text { run }\end{array}$ & \multicolumn{2}{|l|}{ Area $=3335,67 \mathrm{~m}^{2}$} \\
\hline \multirow{7}{*}{$\begin{array}{c}\text { Numerical } \\
\text { data }\end{array}$} & \multirow{2}{*}{ Mesh size } & \multicolumn{2}{|c|}{ Two meshes were used } \\
\hline & & a) $140 \times 150 \times 6$ calculus cells & b) $80 \times 80 \times 12$ calculus cells \\
\hline & Calculus cell size & $0,50 \mathrm{~m} \times 0,50 \mathrm{~m} \times 0,50 \mathrm{~m}$ & $0,25 \mathrm{~m} \times 0,25 \mathrm{~m} \mathrm{x} 0,25 \mathrm{~m}$ \\
\hline & Total number of cells & \multicolumn{2}{|c|}{202800} \\
\hline & Walls limit conditions & \multicolumn{2}{|c|}{ All walls were considered inert } \\
\hline & Floor limit conditions & \multicolumn{2}{|c|}{ The floor (Minimum xOy plan) considered as an inert surface } \\
\hline & Ceiling limit conditions & \multicolumn{2}{|c|}{ The ceiling (Maximum xOy plan) considered inert and closed } \\
\hline \multirow{3}{*}{ Other data } & The source of ignition & \multicolumn{2}{|c|}{$\begin{array}{l}\text { A surface of } 0,80 \mathrm{~m} \times 1,2 \mathrm{~m} \text { at the height of } 0,60 \mathrm{~m} \text {, representing a } \\
\text { portion of the front end of a car, having a heat release rate of } 4 \mathrm{MW} \text {, } \\
\text { [12] and placed near a wall, on the calculus domain floor (figure 5). }\end{array}$} \\
\hline & $\begin{array}{l}\text { Simulated measure } \\
\text { instruments }\end{array}$ & \multicolumn{2}{|c|}{$\begin{array}{l}\text { Through simulated devices inside the calculus domain, the } \\
\text { measurement of smoke propagation speed, of temperature and } \\
\text { visibility was possible. }\end{array}$} \\
\hline & Environment values & \multicolumn{2}{|c|}{$\begin{array}{l}\text { The software's default values: temperature of } 18{ }^{\circ} \mathrm{C} \text {, relative } \\
\text { humidity of } 40 \% \text {, atmospheric pressure of } 101.325 \mathrm{~Pa} \text { and initial air } \\
\text { current speed of } 0 \mathrm{~m} / \mathrm{s} \text {. }\end{array}$} \\
\hline
\end{tabular}

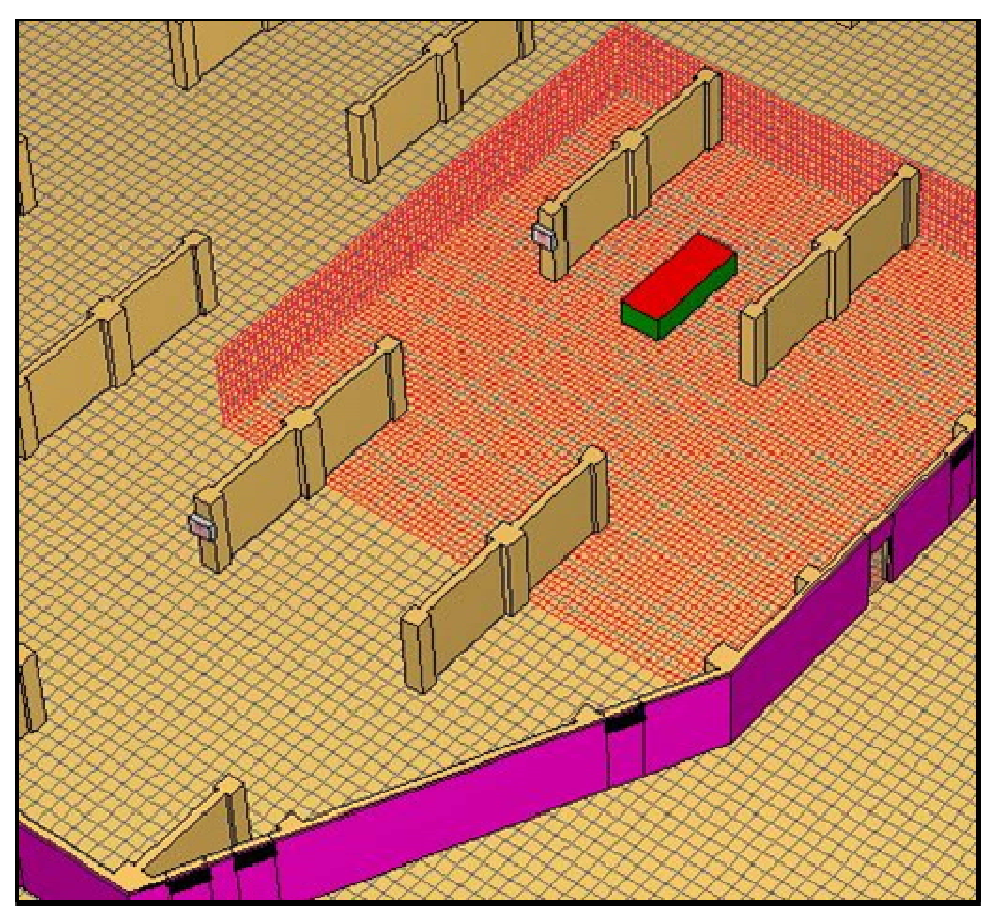

Fig. 5 - Virtual rendition of fire source

\section{Fire scenarios}

A fire scenario is a generalized, detailed description of an actual or a hypothetical, but credible, fire incident, [13]. The fire scenario is mainly just a set of fire conditions. The building fire safety design concept is the solution of more or less well defined predefined variables. Each fire scenario includes all details relevant to the development of a fire and mechanisms of fire protection, [14].

\section{Fire protection}

The building is designed to be sprinkler protected. It is assumed that the sprinklers will control a fire occurring inside the parking area from the early stages. 


\section{Fire location}

The most probable fire scenario takes into account a fire occurring in the sprinkler protected area in the parking building. Given the destination of the building, the fire load will be restricted by the number of cars parked in the vicinity of the fire ignition point.

\section{Fire source}

All of the scenarios selected for the simulation include a fire starting inside a $1.350 \mathrm{~kg}$ car, including $340 \mathrm{~kg}$ of plastic materials and rubber. Different parts of a vehicle are available as fire load, such as the synthetic parts of the body, the interior lining, the rubber tires and the fuel. Several parameters affect the evolution of the fire, such as the ventilation conditions of the car itself (broken or open windows), ventilation conditions inside the car park, the position of the car (close to a wall or not), the distance between neighboring vehicles etc., [15].

\section{Design fire scenario}

The design fire selection has been done taking into account several factors, such as the building characteristics, the ventilation conditions and the fuel characteristics. For all numerical simulations, there has been taken into account an estimated HRR peak of a maximum $4 \mathrm{MW}$.

\section{Particularities}

Fires in underground car parks differ from those in above-ground structures, because the ventilation conditions affect the temperature development. In open car parks, a certain amount of the produced heat will be lost through the open facades, while in underground car parks the hot gases are not able to leave the compartment without forced ventilation and thus will accumulate. This can cause more rapid fire spread. Obviously, radiation feedback from the heated structure will further increase the heat transfer and will cause fire to spread faster, [16].

\subsection{Presentation of Fire Scenario number one}

For this scenario, the sprinkler system is not taken into consideration and the evolution of the fire is assessed, solely by evaluating the efficiency of the smoke evacuation system. The HVAC system is used for smoke evacuation and is activated only when the smoke detectors are activated.

After 10 minutes from the initiation of the fire, the temperature of the ceiling can be observed in figure six, along with smoke distribution. It is clear that the smoke exhaust system alone cannot provide adequate smoke relief in case of a single car fire. For this scenario, the car wasn't located in the vicinity of other combustible materials at the time of the fire, so no propagation can occur.

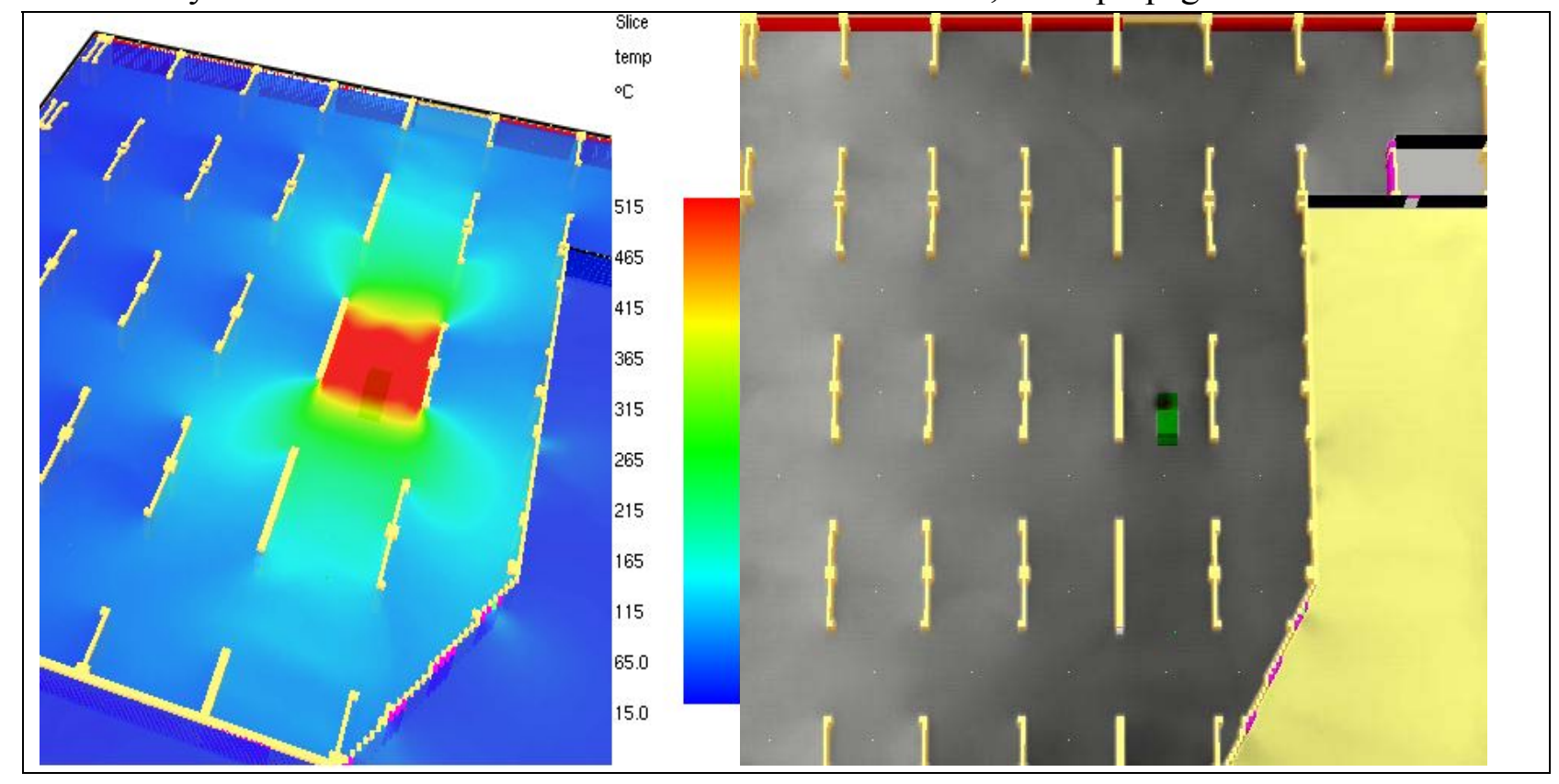

Fig. 6 - Scenario 1 - Ceiling temperature and smoke distribution after 10 minutes from initiation 


\subsection{Presentation of Fire Scenario number two}

For the second scenario, the same conditions apply (as in first scenario), and a valid sprinkler system is added. The smoke detectors in the second scenario didn't activate, because in 217 seconds after the initiation of the fire, the sprinkler activation temperature $\left(68^{\circ} \mathrm{C}\right)$ is reached at the ceiling level, thus the sprinklers were activated. The virtual presentation of the activated fire sprinkler system can be viewed in figure 7 .

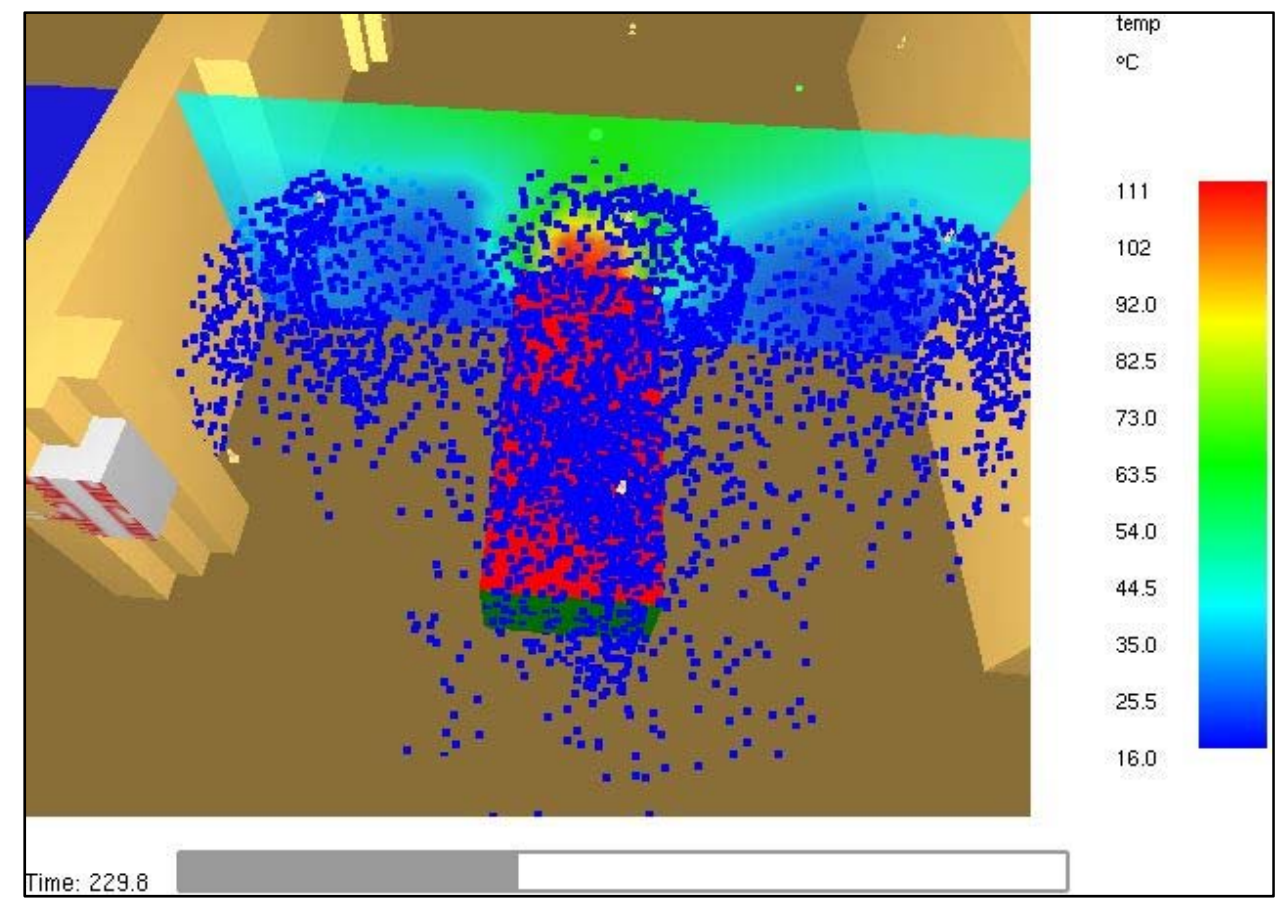

Fig. 7 - Fire Scenario number two - virtual presentation of the three activated sprinkler heads

After 230 seconds from the ignition time, other three sprinklers are activated, so, by the end of the simulation, a total of six sprinklers were activated. In this simulation, the ceiling temperature reached a maximum of $265{ }^{\circ} \mathrm{C}$, in comparison with the $515{ }^{\circ} \mathrm{C}$ of the first simulation. This demonstrates one of the advantages of using sprinkler systems.

The smoke detection and evacuation systems had the same parameters as in the first scenario, but the quantity of smoke produced by the fire was less. The low quantity of smoke was evacuated in a shorter time, as it can be seen in figure 8. Another conclusion from the second scenario is that the smoke movement is slower than in the first scenario, where sprinklers were not taken into account.

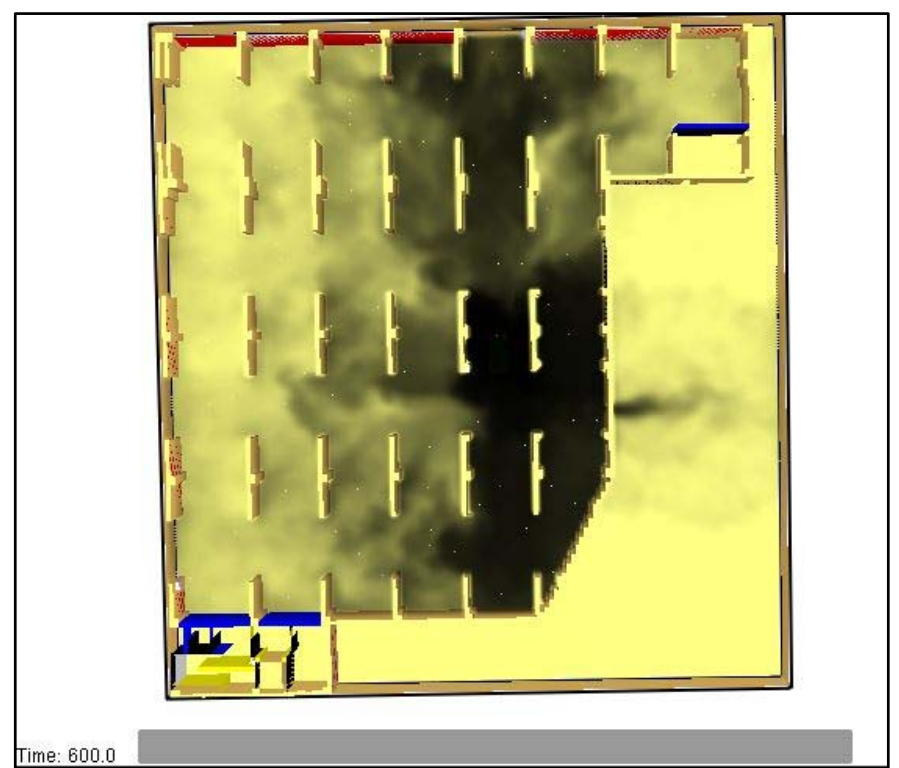

Fig. 8 - Fire Scenario number two - the smoke distribution after 10 minutes from initiation 


\subsection{Presentation of Fire Scenario number three}

In the third scenario, the fire load was greatly increased, by simulating in the vicinity of the first vehicle, a van loaded with construction materials like wood, polystyrene and mineral cladding. All fire safety systems in the building are working in this scenario, with the exception of the sprinkler system. After the ignition of the first car, the fire quickly spreads to the second one, which has been positioned at a distance of $30 \mathrm{~cm}$.

Studies show that the distance between the cars and the direction of the radiation play a crucial role in the ignition times of adjacent cars. In particular, the fire spread was faster than 12 minutes in the case of the vehicles parked 40 and $60 \mathrm{~cm}$ from each other. Even if, in all configurations, a total of seven cars was involved in the fire, the maximum HRR and the amount of combustible materials involved in the fire is slightly higher for a parking distance of $40 \mathrm{~cm}$, [17].

The results were obtained through a simplified model for the fire. As shown in other studies, [18, 19], fire spread quickly takes advantage of the adjacent flammable materials of other cars, such as window rubber seals, tires and paint layers.

During the simulated fire, the ceiling temperature reached values close to $1,000{ }^{\circ} \mathrm{C}$, and the smoke has engulfed all the available space, despite the activation of the smoke evacuation system, as it can be seen in figure 9 .

The fact that a larger quantity of flammable materials is available in this scenario is responsible for the larger quantity of smoke and also for the greater speed of the air currents.

There can be distinguished two main different types of fires spread: fire spread inside a car and fire spread from car to car. Currently, the major interest is in the fire spread from car to car. Fire spread from one vehicle to another can occur in various ways, for example directly by flames or by means of convective or radiative heat transfer. This is illustrated in figure 10, [20].

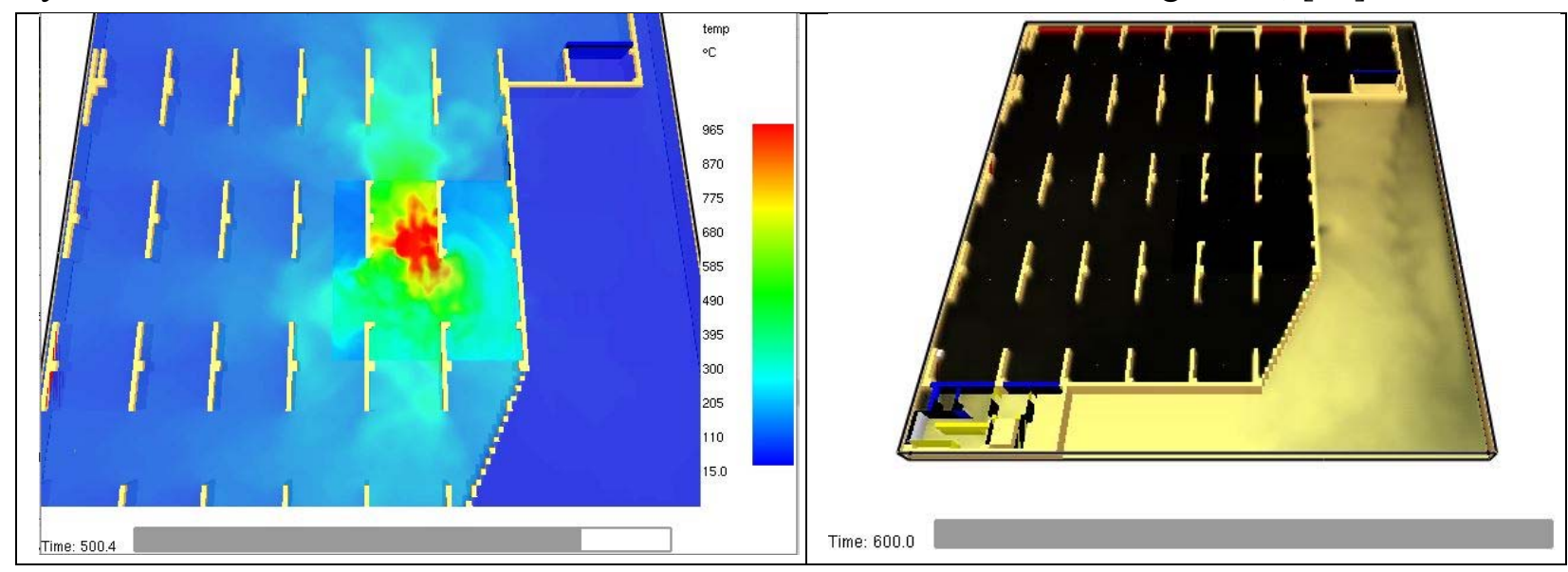

Fig. 9 - Fire Scenario three - Ceiling temperature and smoke distribution

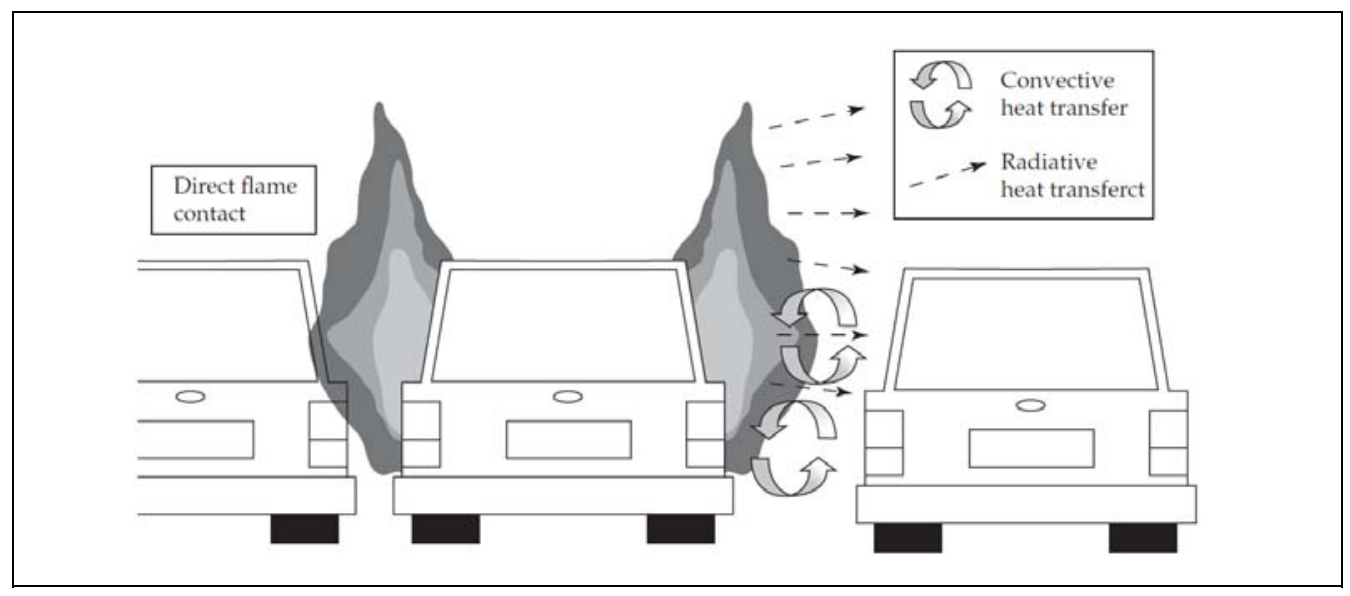

Fig. 10 - Different ways of fire spread; on the left direct fire spread by flame contact, on the right indirect fire spread by heating due to convection and radiation [20] 


\subsection{Presentation of Fire Scenario number four}

In this last simulated scenario, all the conditions are the same as in scenario number three, with the exception that the sprinkler system is valid and taken into account. In about 10 seconds after the fire has spread to the second vehicle, the first sprinkler head activates. After about 270 seconds ( 8 minutes and 30 seconds) from the fire initiation, a total number of 12 sprinkler heads are activated.

The maximum ceiling temperature in this scenario has been $565^{\circ} \mathrm{C}$ and the quantity of smoke that has been released in this instance is lesser than the quantity of smoke which was produced in the third scenario. Both the ceiling temperature values and the smoke distribution at a given moment can be observed in figures 11 and 12 .

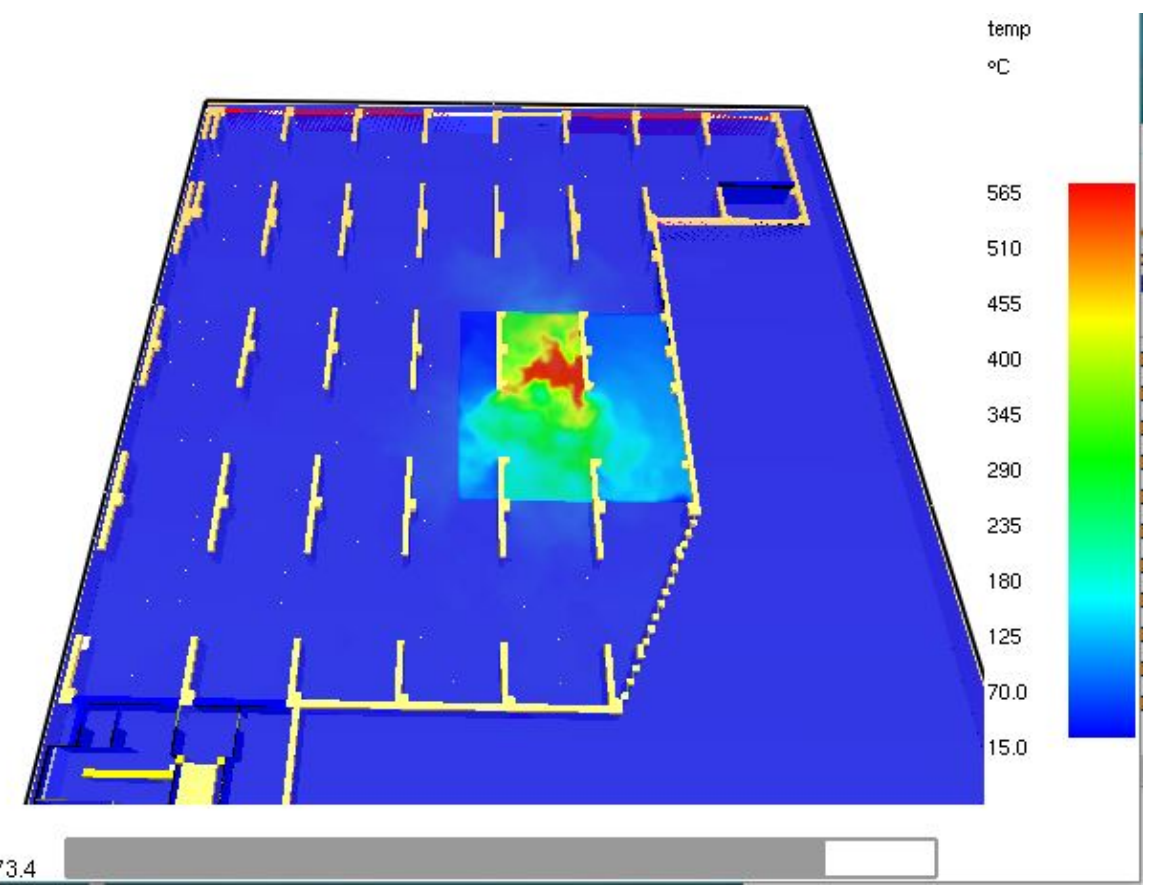

Time: 473.4

Fig. 11 - Fire scenario number four - Ceiling temperature

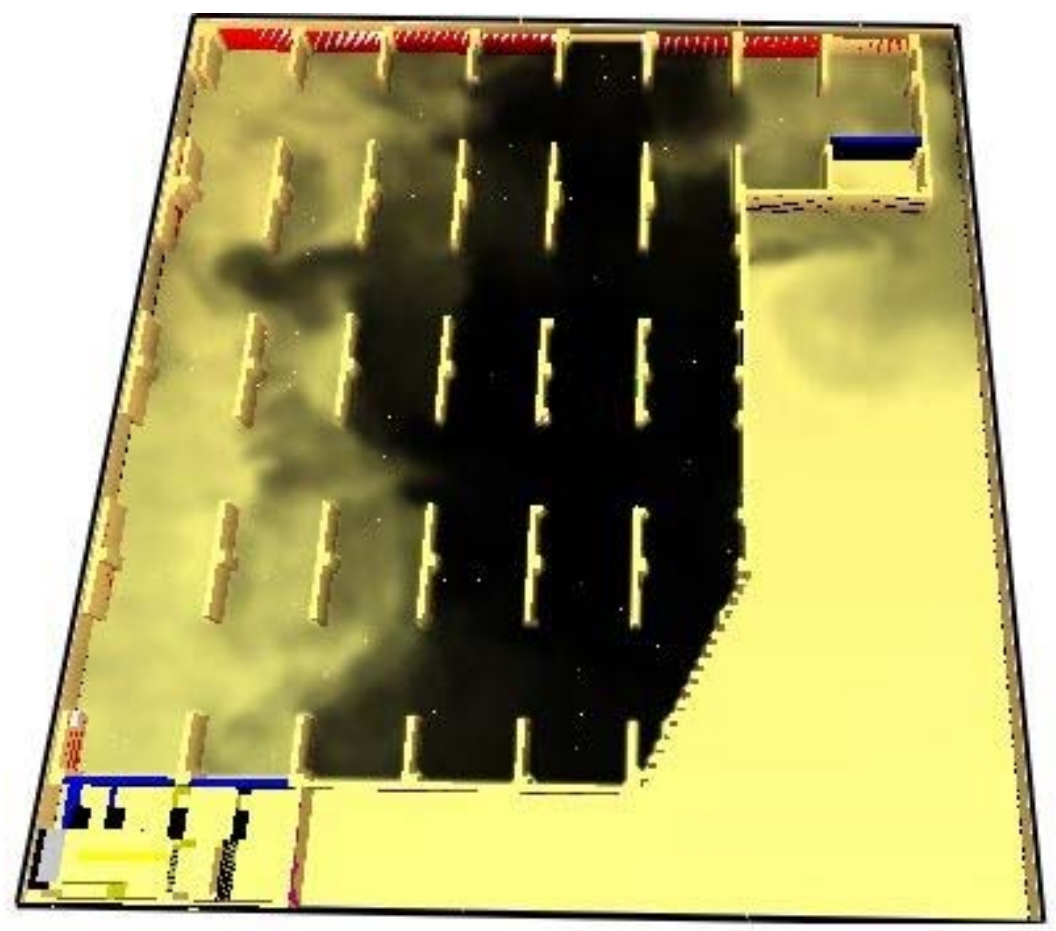

Time: 600.0

Fig. 12 - Fire scenario number four - Smoke distribution 


\section{Conclusions}

The results of different simulations are compared in table 2. The table includes, applied for all simulations, a short description of the scenario, the running time of the simulation, maximum ceiling temperature and the maximum identified value of airflow speed.

Table 2

Computer simulations compiled results

\begin{tabular}{|c|l|c|c|}
\hline \multirow{2}{*}{$\begin{array}{c}\text { Simulation } \\
\text { number }\end{array}$} & \multicolumn{1}{|c|}{ Short description of the scenario } & \multicolumn{2}{|c|}{ Simulation results } \\
\cline { 3 - 4 } & & $\begin{array}{c}\text { Maximum ceiling } \\
\text { temperature }\end{array}$ & $\begin{array}{c}\text { Maximum } \\
\text { airflow speed }\end{array}$ \\
\hline \hline 1 & $\begin{array}{l}\text { Fire involving one vehicle, only smoke } \\
\text { detection and exhaust systems are active. }\end{array}$ & $515^{\circ} \mathrm{C}$ & $1 \mathrm{~m} / \mathrm{s}$ \\
\hline 2 & $\begin{array}{l}\text { Fire involving one vehicle, smoke detection, } \\
\text { exhaust and sprinkler systems are active. }\end{array}$ & $265^{\circ} \mathrm{C}$ & $0,65 \mathrm{~m} / \mathrm{s}$ \\
\hline 3 & $\begin{array}{l}\text { Fire involving two vehicles, only smoke } \\
\text { detection and exhaust systems are active. }\end{array}$ & $965^{\circ} \mathrm{C}$ & $2 \mathrm{~m} / \mathrm{s}$ \\
\hline 4 & $\begin{array}{l}\text { Fire involving two vehicles, smoke detection, } \\
\text { exhaust and sprinkler systems are active. }\end{array}$ & $565^{\circ} \mathrm{C}$ & $1,5 \mathrm{~m} / \mathrm{s}$ \\
\hline
\end{tabular}

Computer simulation can be a cheaper alternative to real scale tests and can provide important data regarding the effects of a fire on the surroundings, the way that smoke might evolve, visibility in certain key points (important for the evacuation of occupants) and the degree of damage that the building is subjected to in the event of a fire.

The present article confirms and underlines the importance of sprinkler fire suppression systems and provides a certain measure of the impact that they can have on the evolution of a fire. In the case of the analyzed building, the safety of the inhabitants in the case of fire initiating in the parking space, is closely related to the normal and adequate performance of the sprinkler system.

The capacity of the smoke exhaust system is also measured and the overall interdependence of the fire safety systems is presented, in the sense that, as shown, they all have to perform well, in order to provide the required fire safety level.

- Some of the conclusions in reference [14] were confirmed, such as:

- the action of sprinklers to control the spread of fire limits the HRR to effectively the same scenario of an old car burning without any spread to another car;

- ventilation and extraction systems have limited effectiveness in fires, although they may be required at low flow rates for removal of car exhaust gases.

This paper presents a global fire risk assessment of an underground car park using four fire scenarios. The main differences in-between scenarios are the value of the fire load density the existence of an active fire protection systems.

\section{Acknowledgement}

This work was supported by a grant of the Romanian Ministry of Research and Innovation, CCCDI - UEFISCDI, project number PN-III-P1-1.2-PCCDI-2017-0350/ 38PCCDI within PNCDI III.

\section{References}

[1] Dârmon, R. (2017). Probabilistic Risk Assessment for an Art Timber Structure within an Atrium Space. In Advanced Engineering Forum (Vol. 21, pp. 50-57). Trans Tech Publications.

[2] Dârmon, R., \& Suciu, M. (2018). Smoke ventilation strategy for a timber structure building. Procedia Manufacturing, 22, 249-255.

[3] McGrattan, K., Hostikka, S., McDermott, R., Floyd, J., Weinschenk, C., \& Overholt, K. (2013). Fire dynamics simulator technical reference guide volume 1: mathematical model. NIST special publication, 1018(1), 175. 
[4] McGrattan, K., Klein, B., Hostikka, S., \& Floyd, J. (2013). Fire dynamics simulator (version 6), user's guide. NIST special publication, 1019(6).

[5] Eng, T. (2011). PyroSim User Manual. The RJA Group Inc, Chicago, USA.

[6] Zhang, X. G., Guo, Y. C., Chan, C. K., \& Lin, W. Y. (2007). Numerical simulations on fire spread and smoke movement in an underground car park. Building and environment, 42(10), 3466-3475.

[7] NORMATIV de securitate la incendiu a parcajelor subterane pentru autoturisme, indicativ NP 127:2009

[8] MZ, M. T., \& Spearpoint, M. I. C. H. A. E. L. (2014). Development of fire scenarios for car parking buildings using risk analysis. Fire Safety Science, 11, 944-957.

[9] Normativ pentru proiectarea, executarea și exploatarea instalațiilor de stingere a incendiilor, indicativ NP 086 - 05.

[10] Normativ pentru proiectarea construcțiilor publice subterane, indicativ NP $25-97$.

[11]Truchot, B., Fouillen, F., \& Collet, S. (2018). An experimental evaluation of toxic gas emissions from vehicle fires. Fire Safety Journal.

[12] Collier, P. C. R. (2011). Car Parks: Fires Involving Modern Cars and Stacking Systems. BRANZ.

[13] J. M.Watts, Fire Scenarios, Fire Technol., 1991, 27, 289-290.

[14] Jug, A., Petelin, S., \& Bukovec, P. (2010). Designing an underground car park fire scenarios on a probabilistic basis. Acta chimica Slovenica, 57(1).

[15] Merci, B., \& Shipp, M. (2013). Smoke and heat control for fires in large car parks: Lessons learnt from research? Fire safety journal, 57, 3-10.

[16] Annerel, E., Taerwe, L., Merci, B., Jansen, D., Bamonte, P., \& Felicetti, R. (2013). Thermo-mechanical analysis of an underground car park structure exposed to fire. Fire Safety Journal, 57, 96-106.

[17]Márton, T., Dederichs, A., \& Giuliani, L. (2016). Modelling of Fire in an Open Car Park. Applications of Structural Fire Engineering.

[18]Jiang, X. H., Zhu, G. Q., Zhu, H., \& Li, D. Y. (2018). Full-scale Experimental Study of Fire Spread Behavior of Cars. Procedia Engineering, 211, 297-305.

[19] Tohir, M., \& Zahirasri, M. (2015). Multiple vehicle design fire scenarios in car parking buildings.

[20] Noordijk, L., \& Lemaire, T. (2005). Modelling of fire spread in car parks. Heron, 50(4), 209-218. 